\title{
Using financial analysis to assess brand equity
}

Article in Journal of Product \& Brand Management · February 2013

DOI: $10.1108 / 10610421311298713$

CITATIONS

8

2 authors:

Steven Isberg

University of Baltimore

9 PUBLICATIONS 180 CITATIONS

SEE PROFILE
READS

85

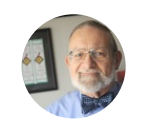

Dennis A. Pitta

University of Baltimore

88 PUBLICATIONS 1,290 CITATIONS

SEE PROFILE

Some of the authors of this publication are also working on these related projects:

Project

The Role of Integrated Marketing Communications in Sustainability Marketing, Proceedings of American Society of Business and Behavioral Sciences View project

Project

Privacy Issues View project

All content following this page was uploaded by Dennis A. Pitta on 26 May 2017. 


\title{
Using financial analysis to assess brand equity
}

\author{
Steven Isberg and Dennis Pitta \\ University of Baltimore, Baltimore, Maryland, USA
}

\begin{abstract}
Purpose - The purpose of this article is to describe a method of assessing brand equity quantitatively. Design/methodology/approach - The article describes an example of analysis using publicly available financial data to assess brand equity. Findings - Brand equity measurement has been an elusive goal for product managers. While qualitative definitions are available, few studies have attempted to quantify a product or company's brand equity. Using financial analysis techniques focusing on return on equity and return on assets, the case examines the results of two distinct brand equity growth strategies. The first is growth by acquisition; the second, organic brand development. Using historical financial data for the Safeway corporation, the case calculates the brand equity effects of two distinct marketing strategies. In the example, organic brand development, the traditional task of the brand manager, results in higher brand equity.

Research limitations/implications - As in all case studies, the specific conditions found in one organization may not be found more generally in others. Readers are cautioned that the conclusions drawn may have limited applicability.

Practical implications - The work illustrates a technique that a product/service manager may use to assess the brand equity effects of a marketing strategy. Originality/value - The work describes a technique not widely publicized in the brand literature.
\end{abstract}

Keywords Online retailing, Business-to-business marketing, Direct mail, Internet sales, Differentiation, Brand equity, Quantitative measurement, Financial value of brand equity, Internet shopping, Marketing strategy, Electronic commerce, Retailing

Paper type Case study

\section{Introduction}

Product managers create brand equity using a combination of marketing tactics that comprise a marketing strategy. Managers assess the effectiveness of such brand strategies by relying on metrics such as market share growth, profitability, or others such as brand equity value. Measuring brand equity value has been elusive. There are several qualitative descriptions but there is no commonly accepted quantitative measure of changes in brand equity. Financial analysis can provide some insight into how brand managers can calculate brand equity.

Two relatively simple measures, return on equity or "ROE" and return on assets "ROA" can provide such information. The following text explains the use of both measures and illustrates a publically traded company's attempts to implement two distinct marketing strategies. Using the two measures, product managers with access to their brand's financials can calculate the effect of their efforts to build equity and succeed.

\section{A financial perspective on measuring brand performance}

Over the years, qualitative definitions such as "brand equity is the loyalty of the customer base," conveyed that some brands

The current issue and full text archive of this journal is available at www.emeraldinsight.com/1061-0421.htm

Journal of Product \& Brand Management

22/1 (2013) 65-78

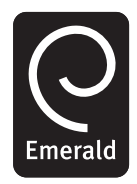

(C) Emerald Group Publishing Limited [ISSN 1061-0421]

[DOI 10.1108/10610421311298713] had this important characteristic. This type of definition does not provide the basis for evaluative or comparative analysis: such tasks require a more precise metric. Analysis of financial data offers the promise of developing such measures and has been applied to branding in the past (Mizik and Jacobson, 2008). Financial data analysis also offers one metric for assessing the success of a range of brand management activities including strategies designed to build market share (Ward and Ryals, 2001; Simon and Sullivan, 1993).

Understanding the impact of a brand development strategy on corporate value is of critical importance to brand managers. Unsuccessful strategies will inevitably lead to declining equity values, leaving companies vulnerable to takeover and other forms of restructuring which, although voluntary, may not be desirable (e.g. downsizing, spin-offs, etc.). The impact of strategy on value can be understood through the use of financial statement and ratio data, specifically, by understanding how the strategy affects different factors driving the return on shareholder equity (ROE) and stock price.

If a company has publicly traded equity, brand equity value will be reflected in the price of its shares. For privately held firms, the best measure of added value is the impact of the strategy on the return on the owner's equity investment, "ROE."Since the ROE is also tied to the share value of publicly traded companies, it provides a good basis for evaluating the effectiveness of a brand management strategy in general.

ROE essentially measures the rate at which the value of the owners' investment in a company is increasing. Investors use this concept to determine whether a company is providing adequate compensation for the risk inherent in owning shares in the firm. 
ROE is driven by a company's operating performance and financial strategies. Brand management strategies are a key determinant of the company's operating performance, and therefore, a key driver of the ROE. Evaluating the impact of a brand management strategy on the ROE, therefore, can be helpful to brand and other managers in determining the success of those strategies.

Brand management strategies can impact the ROE by way of enhancing profit margins, sales volume, or some combination of the two. For example, a high-end branding strategy may focus on maximizing profit margins as opposed to targeting the higher sales volume that might accompany a mass-market branding strategy. Analysis of the components of the ROE, therefore, will assist the brand manager in understanding whether the strategy is accomplishing what it set out to do.

The ROE is a financial concept measuring profitability relative to the amount of equity invested in a company. Its calculation is very simple:

$$
\mathrm{ROE}=\mathrm{NI} / \mathrm{TE}
$$

where:

$\mathrm{NI}=$ net income,

$\mathrm{TE}=$ average total equity

It can also be broken out into three concepts that measure the impact of profitability, sales volume, and financial policy on the value of a firm. The best way to see and understand this is by way of the DuPont expansion, which shows that the ROE is actually a product of net profitability, total asset turnover, and a leverage multiplier, as follows:

$$
\mathrm{ROE}=(\mathrm{NI} / \mathrm{S})^{*}(\mathrm{~S} / \mathrm{TA})^{*}(\mathrm{TA} / \mathrm{TE})
$$

where:

$\mathrm{NI}=$ net income.

$\mathrm{TE}=$ average total equity

$\mathrm{S}=$ Sales.

$\mathrm{TA}=$ average total assets.

This can also be expressed as:

$$
\begin{aligned}
\mathrm{ROE}= & \text { Net Profit Margin }{ }^{*} \text { Total Asset Turnover } \\
& * \text { Leverage Multiplier }
\end{aligned}
$$

While the net profit margin can be used to assess a brand management strategy's impact on profitability, the total asset turnover can be used as a measure of its impact on sales volume. The third component of the ROE, the leverage multiplier (TA/TE), measures the impact of financial leverage on the ROE. Generally speaking, this "leverage multiplier" will increase the ROE when profits are positive, and accelerate the reduction in the ROE when profits are negative. Since it is a consequence of decisions made regarding the use of debt and equity financing, we would not expect it to be influenced by brand management strategies.

These first two components of the ROE compose the return on assets (ROA):

$$
\mathrm{ROA}=\mathrm{NI} / \mathrm{TA}=(\mathrm{NI} / \mathrm{S})^{*}(\mathrm{~S} / \mathrm{TA})
$$

or

$$
\text { ROA }=\text { Net ProfitMargin }{ }^{*} \text { Total Asset Turnover }
$$

An effective brand management strategy should have an impact on the ROE by way of the ROA, either by enhancing profitability, increasing relative sales volume, or both.

\section{The allocation of financial capital toward brand development strategies}

In essence, financial resources can be invested in three possible brand-building strategies. The traditional approach is to devote financial resources to support marketing efforts to internally develop a new brand. Alternatively, one could invest that money in support of an existing brand that is under competitive pressure. These are both "organic" brand development strategies in that they are designed to grow a brand from within the company. The third approach is to acquire a new or existing brand by way of purchasing from or merging with another company. The third approach could be referred to as "external brand acquisition."

The purest approach to the goal of building market share would be to position a brand carefully and devote appropriate marketing and merchandising resources to increase consumer preference, in essence, an organic brand development strategy. Such brand development is the most typical brand equity building strategy in the minds of marketers. According to M'zungu et al. (2010), building internal strengths along with creating a consistent brand mindset and delivery program exemplify activities considered important to protecting and increasing brand equity. However, in practice, focusing exclusively on the company's existing brands may not achieve the desired market share increases. External brand acquisition relies on adding brands developed by others to increase the value of the brand portfolio.

Marketing managers are aware that it may be very difficult or costly to buy a successful brand. External brand acquisition has been common in a variety of cases in which shakeouts leading to consolidation leave an industry with a smaller number of larger, more profitable competitors, often taking advantages of economies of scale. The solution for brands with low market share is often to combine with another competitor in some kind of merger or acquisition transaction. Examples of such external brand acquisition can be found in industries like brewing, department stores, and hospitality and retail establishments. One particularly important example of brand building by acquisition is the retail grocery sector.

The following analysis attempts to evaluate the brand equity effects of external brand acquisition as compared to organic brand development. The data employed in the study are gathered from the Security and Exchange Commission's (SEC) Form 10-K annual disclosures of financial information. The focal company, Safeway, is an interesting example because it employed both external and organic strategies during a period of shakeout and consolidation in the retail grocery industry. The objective of the analysis is to provide brand managers access to a set of tools and language that can be used to assess the success of a branding strategy in the context of the chief corporate goal of maximizing the value of the shareholders' stake in the firm.

\section{Safeway's external brand acquisition strategy: 1996-2003}

Pressure to build brand strength resulted from WalMart's aggressive entry into the retail grocery sector in the late 1990s. 
It was one of the main factors contributing to the consolidation underway in the industry at the time. WalMart reset the standard for supply chain efficiency, leading many companies to seek to develop economies of scale and geographically widespread markets in order to compete with WalMart's national branding and distribution strategies. At the same time, WalMart's position as the industry price leader put pressure on competitors to hold the line on prices, in spite of the fact that the general movement toward consolidation, which would leave the industry with fewer competitors, allowing both prices and profit margins to increase.

Many competitors responded to these changes by pursuing growth-by-acquisition strategies. The Safeway Company was a prime example. Their acquisitions in the late 1990s included the Texas-based Randall's Food Markets, Carr's (Alaska), and Dominick's (Illinois). In 2001, Safeway added the Genuardi's chain, doing business in Pennsylvania, Delaware, and New Jersey.

Safeway was pursuing an external brand acquisition strategy in purchasing these four and other grocery store chains. Brand name and recognition had always been an important part of Safeway's strategy. As stated in its annual 10-K report for FY 2001:

Safeway has invested significantly in the development and protection of the "Safeway" name. The right to use the "Safeway" name is considered to be an important asset. Safeway also owns approximately 400 other trademarks registered or pending in the United States Patent and Trademark Office, including its product line names such as Safeway, Safeway SELECT, Lucerne and Mrs. Wright's, and the marks Pak n' Save Foods, Vons, Pavilions, Dominick's, Carrs, Randalls, Tom Thumb and Genuardi's Family Markets. Each trademark registration is for an initial period of 10 or 20 years and is renewable for as long as the use of the trademark continues. Safeway considers certain of its trademarks to be of material importance to its business and actively defends and enforces such trademarks.

These acquired brands were at the time associated with a certain degree of upscale quality within their local markets. Stock market values were also running hot due to the growth and development of the technology bubble in the late 1990s. As such, Safeway paid significant premia over and above book value in making these acquisitions.

The impact of the strategy on Safeway's total assets was striking. As can be seen in Figure 1, total assets more than tripled to a level of $\$ 17.50$ billion. Over 45 percent of that growth, $\$ 5.385$ billion, was due to an increase in store and other facilities (net property, plant, and equipment or PP\&E), and 40 percent, $\$ 4.761$ billion, represented an increase in intangible assets, representing the premia paid for the brand and other assets acquired in these transactions. This increase in assets would reduce the ROE unless the company made gains in sales volume, profitability, or some combination of the two.

Inventory, physical store spaces, and brand names are the three most important assets to a face-to-face retailer. Safeway was more heavily invested in all three by the end of 2001 . Ultimately, in order for such brand acquisition to add value to the firm, sales and earnings would have to grow at least proportionately to the increase in asset investment, including the goodwill and other intangibles (Bahadir et al., 2008).

The initial stock market response to the commencement of the growth by acquisition strategy appears to have been favorable. As can be seen in Figure 2, Safeway's stock price at the beginning of January 1996 was $\$ 11.44$ per share (on a split adjusted basis). By December 1998, the stock was trading at over $\$ 54$ per share, a compound annual growth rate of 71 percent.

Some of this increase may have been due to the overall stock market euphoria brought about by the tech boom of the late 1990s. As can also be seen in Figure 2, the stock value declined between December 1998 and October 1999, when it bottomed out at $\$ 31.68$ per share. By December 2000, however, the stock was trading at $\$ 56$ per share, fully recovering from the loss associated with the tech bust of that year. From that point on, however, the situation changed.

\section{Evaluating Safeway's performance: 1996-2003}

As mentioned above, a successful brand acquisition strategy should be characterized by growing sales and profits. Profit performance can be measured at three levels using the gross, operating, and net profit margins, the third of which is the first element in the DuPont ROE. Gross profit margin will provide insights on relationships between the firm's pricing strategies and its average unit cost, which may be affected by the creation of economies of scale through the acquisition process. Whether the gross margin rises or falls is not nearly as important, however, as what happens to the operating profit. While gross profit margin is sensitive to pricing, product mix, and unit costs, it is not driven by sales volume. Operating margin, on the other hand, is more responsive to changes in sales volume due to the fixed nature of many operating expenses.

Higher end branding is often accompanied by increased fixed costs of marketing and advertising. Higher-end store locations with better lighting and other features are often more expensive to operate. These costs must be covered by higher sales volume.

Eventually, operating profits contribute to the ROE by way of their impact on the net profit margin. The higher the value of the operating margin, the greater value of the net margin. Since operating expenses can be both variable and fixed, operating margins will often rise with sales volume, even though gross profit margins may remain the same.

Increased sales volume will increase the ROA, and hence the ROE, by way of increasing both the operating profit margin AND the asset turnover. Overinvestment in assets, however, which includes paying too much for acquisitions, could wipe out the impact of rising profitability as it increases the denominator in the turnover ratio and lowers the ROA and ROE.

What investors saw in Safeway by the beginning of 2001 appears to be a lack of adequate sales growth accompanying the brand acquisition strategy. As can be seen in Figure 3, sales increased between 1997 and 2001, but only at an 11.11 percent annual rate, to a level of $\$ 34.30$ billion. At the same time, Safeway's gross margin increased by 268 basis points, up to a level of 33.24 percent, at a time when gross margins for WalMart were in the mid-20 percent range. This implies that Safeway either raised its prices or did not pass any of the cost savings resulting from acquired economies of scale back to its customers, resulting in a negative impact on sales growth.

Even though Safeway's gross and, in fact, operating and net profit margins increased between 1997 and 2001, its return on assets fell due to a decrease in the total asset turnover. As shown earlier, Safeway's asset level grew as a result of the acquisition strategy. As can be seen in Figure 4, however, 
Figure 1 Safeway Company

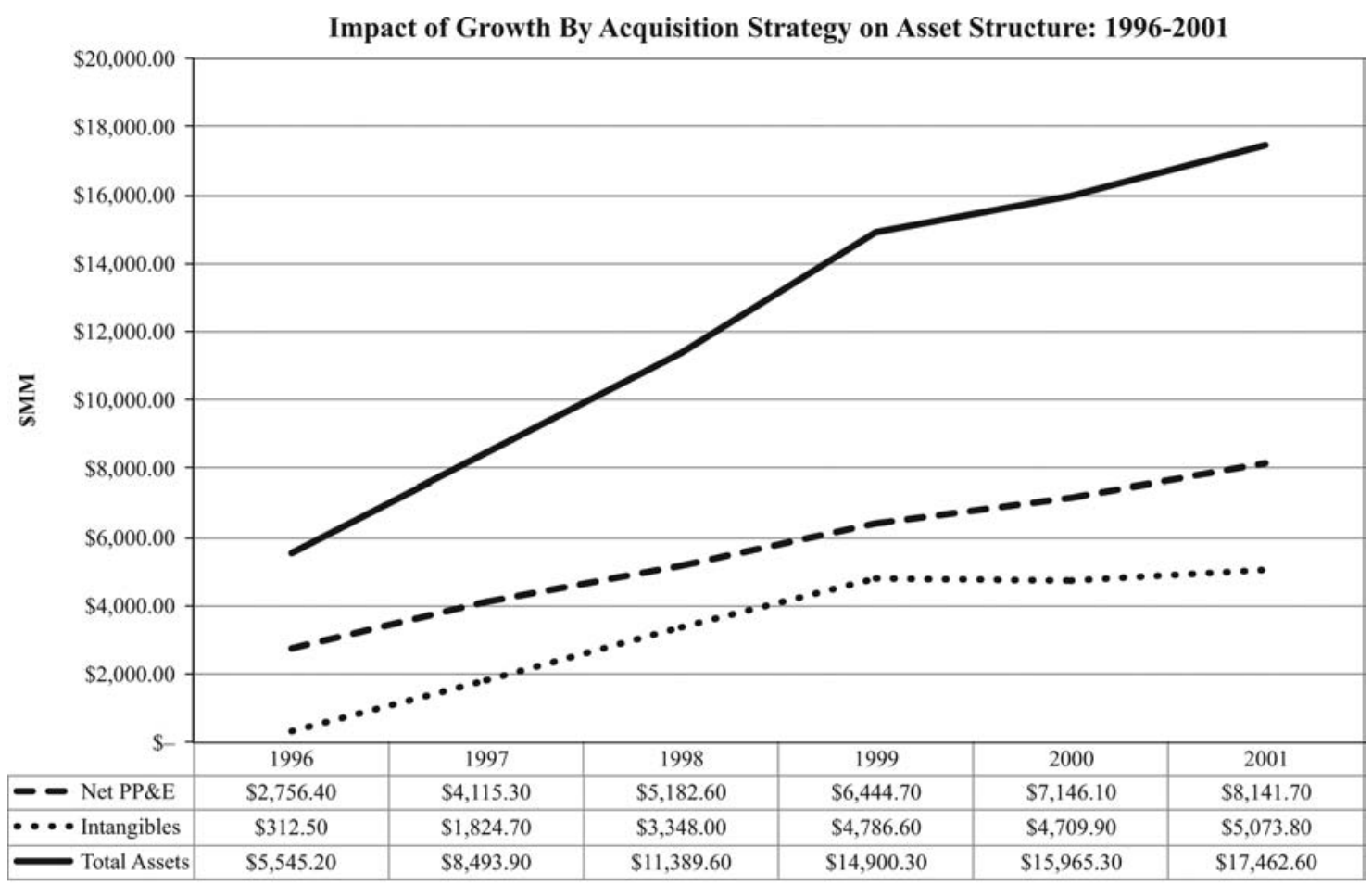

Source: S\&P Capital IQ-Compustat North American database

Figure 2 Safeway Company

Monthly Stock Price (Adjusted for Splits): Jan. 1996-Dec. 2001

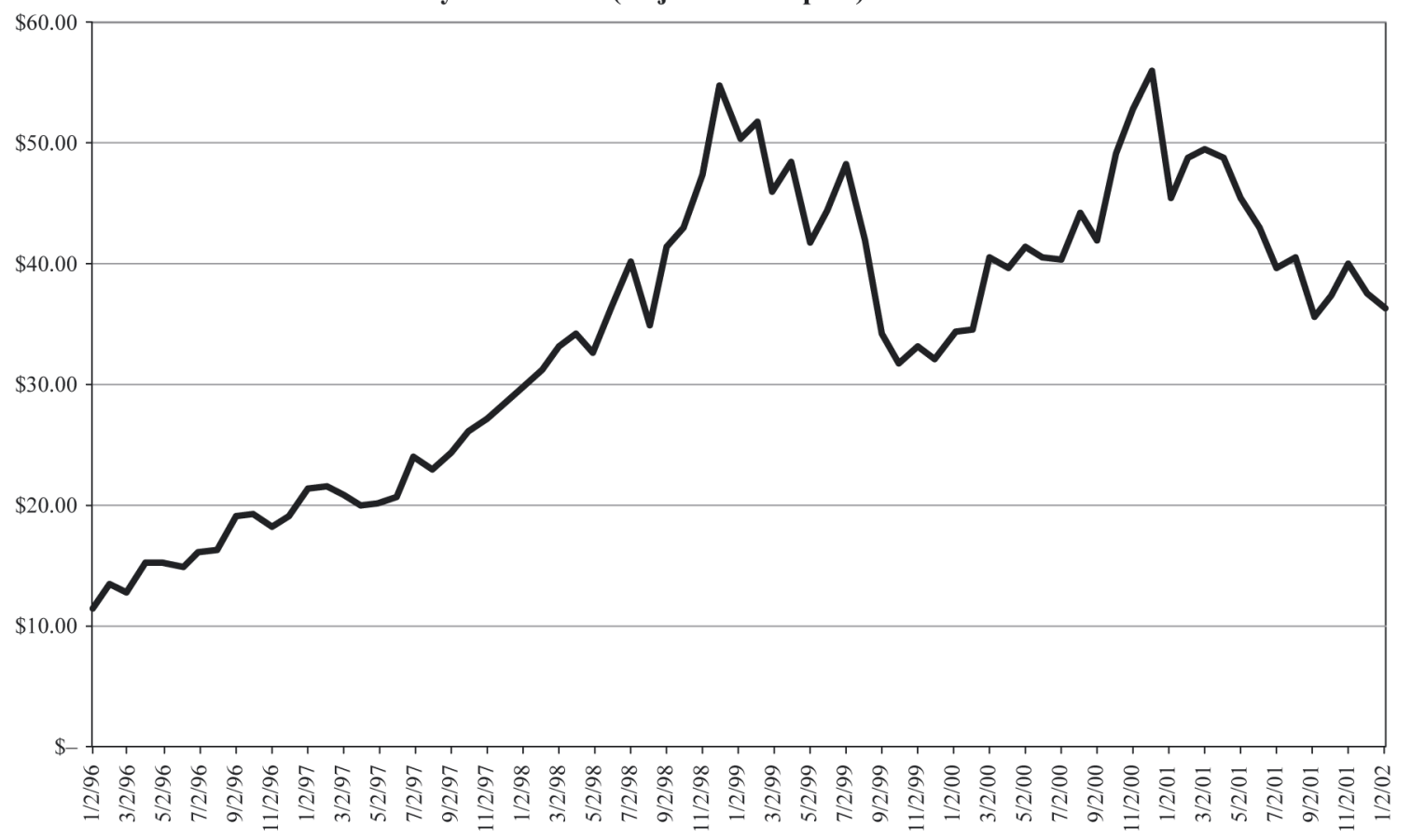

Sources: Finance.Yahoo.com; Stock prices adjusted for dividends 
Figure 3 Safeway Company

Impact of Growth By Acquisition Strategy on Sales and Gross Margin: 1997-2001

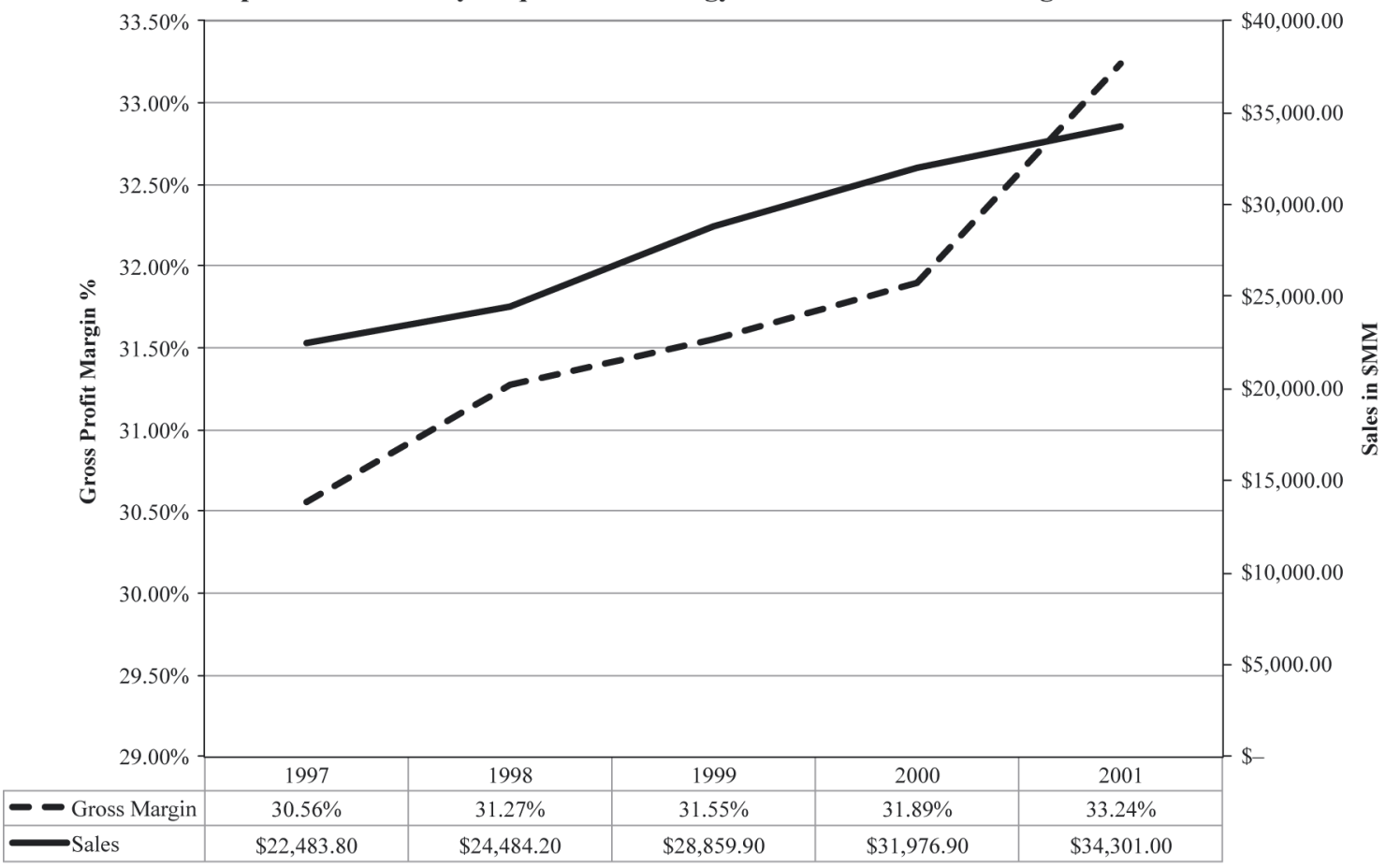

Source: S\&P Capital IQ-Compustat North American database

falling total asset turnover led to a declining return on assets in spite of the increase in overall profitability during that same time period. The increased investment in assets, a large part of which were brand-related goodwill and other intangibles, was not returning additional sales growth at the same rate.

Total asset turnover is a good leading indicator of success or failure. Increases in asset turnover often lead to enhanced profit performance. Decreasing asset turnover implies falling relative sales volume. While not necessarily a problem in the short run, falling relative sales volume will adversely affect the long-term prospects of an operating strategy by reducing the capital needed to sustain it. Asset turnover, therefore, is often a key element in models that predict financial distress.

Safeway was also failing to generate adequate additional sales volume out of its increased investment in physical store facilities. As can be seen in Figure 5, sales per square foot of store space initially increased in the first three years of the growth by acquisition strategy (i.e. from $\$ 447$ to $\$ 481$ between 1998 and 2000). By 2002, however, sales per square foot had fallen to $\$ 434$. As can also be seen in Figure 5, sales per dollar invested in net PP\&E (i.e. Net PP\&E turnover) steadily fell from $\$ 5.267$ in 1998 to $\$ 4.012$ in 2002 . Essentially, each dollar invested in physical store space was generating about $\$ 1.26$ less in sales as a result of the acquisition strategy. The lower PP\&E turnover contributed to the ROE by way of its reducing total asset turnover.

\section{Shifting strategy: focus on buoying the stock price: 2001-2003}

By the end of 2001, a declining return on equity (ROE), was leading to a steadily declining stock price, and Safeway was beginning to act in a defensive manner. As can be seen in Figure 6, ROE fell from 37.26 percent in 1997 to 22.23 percent in 2001. By the end of 2001, the stock price had also begun to fall. Seeing this, Safeway management had already begun to divert its cash flows into a leveraged stock repurchase program. This is evident in the pattern visible in Figure 7, which shows increases in both long-term debt and cumulative treasury stock repurchases from 1998 to 2002, especially in the latter two years.

Stock repurchase programs are used for a variety of purposes. In this case, the action of Safeway moving into the market to purchase shares would belay the falling market price. By simultaneously adding debt and disgorging the cash, Safeway was also making itself into a less attractive takeover target at a time when they would have been vulnerable as such. At the same time, however, it made the share value depend on the company's financial rather than its operating strategies. It is questionable as to whether this would be sustainable in the longer run.

The stock repurchase program at best kept the stock from hitting rock bottom. As can be seen in Figure 8, the stock price continued to fall from $\$ 40.39$ in March 2002 to $\$ 14.91$ in April 2003. By then, Safeway had already begun to writedown (impair) the value of some of the goodwill it had acquired between 1997 and 2001. Prior to FASB 142, it was allowable to amortize goodwill along with other intangible assets. This was often thought to have led to overvalued acquisition premia, particularly in the financial services industry. FASB 142 requires goodwill to be permanently retained on the balance sheet and periodically reviewed for impairment. By impairing, or writing down the value of acquired assets, Safeway was essentially admitting that it had paid too much for them. 
Figure 4 Safeway Company

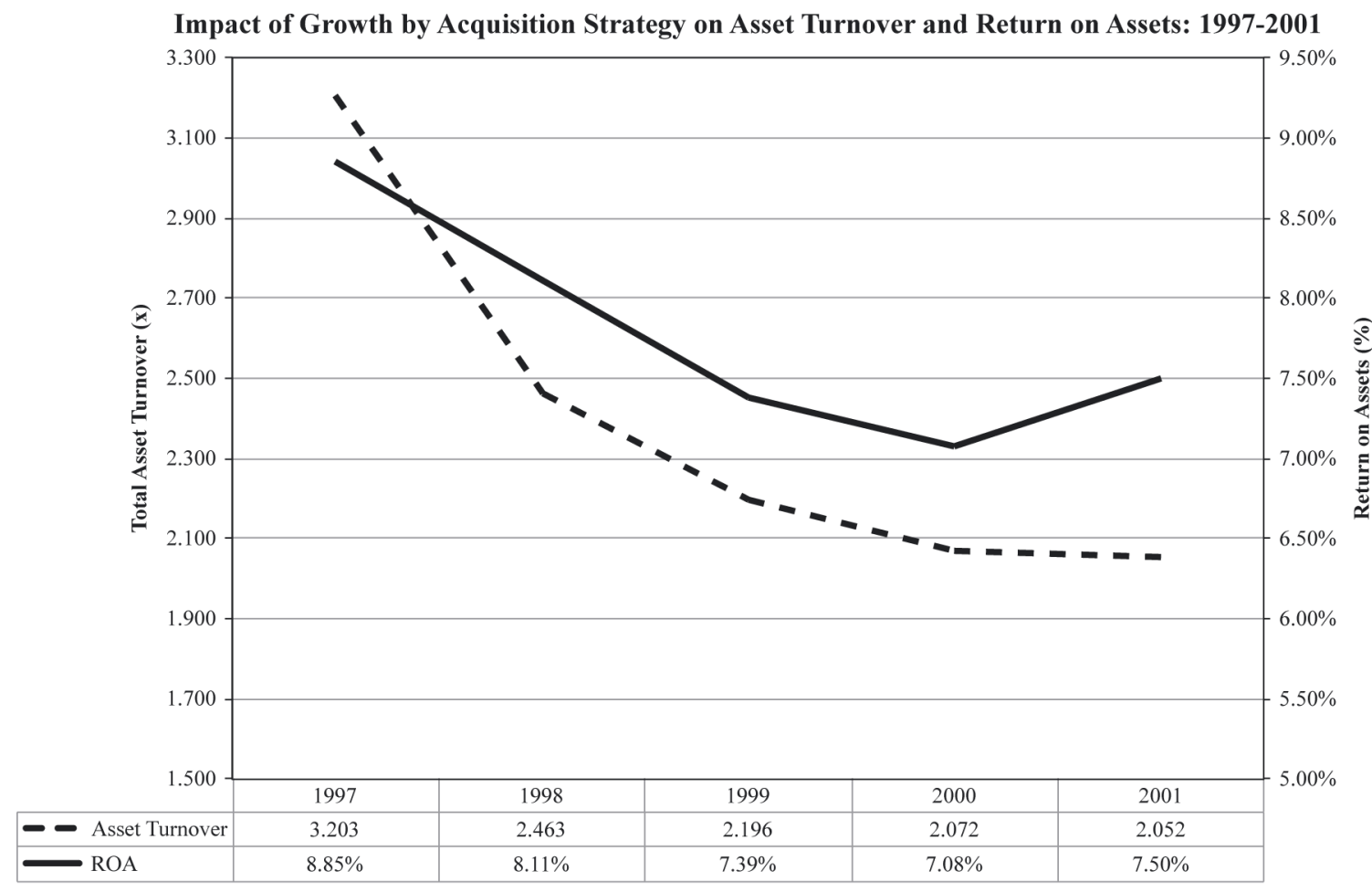

Source: S\&P Capital IQ-Compustat North American database

Figure 5 Safeway Company

Impact of Growth by Acquisition Strategy on Sales per Square Foot and Plant,

Property, \& Equipment Turnover: 1998-2002

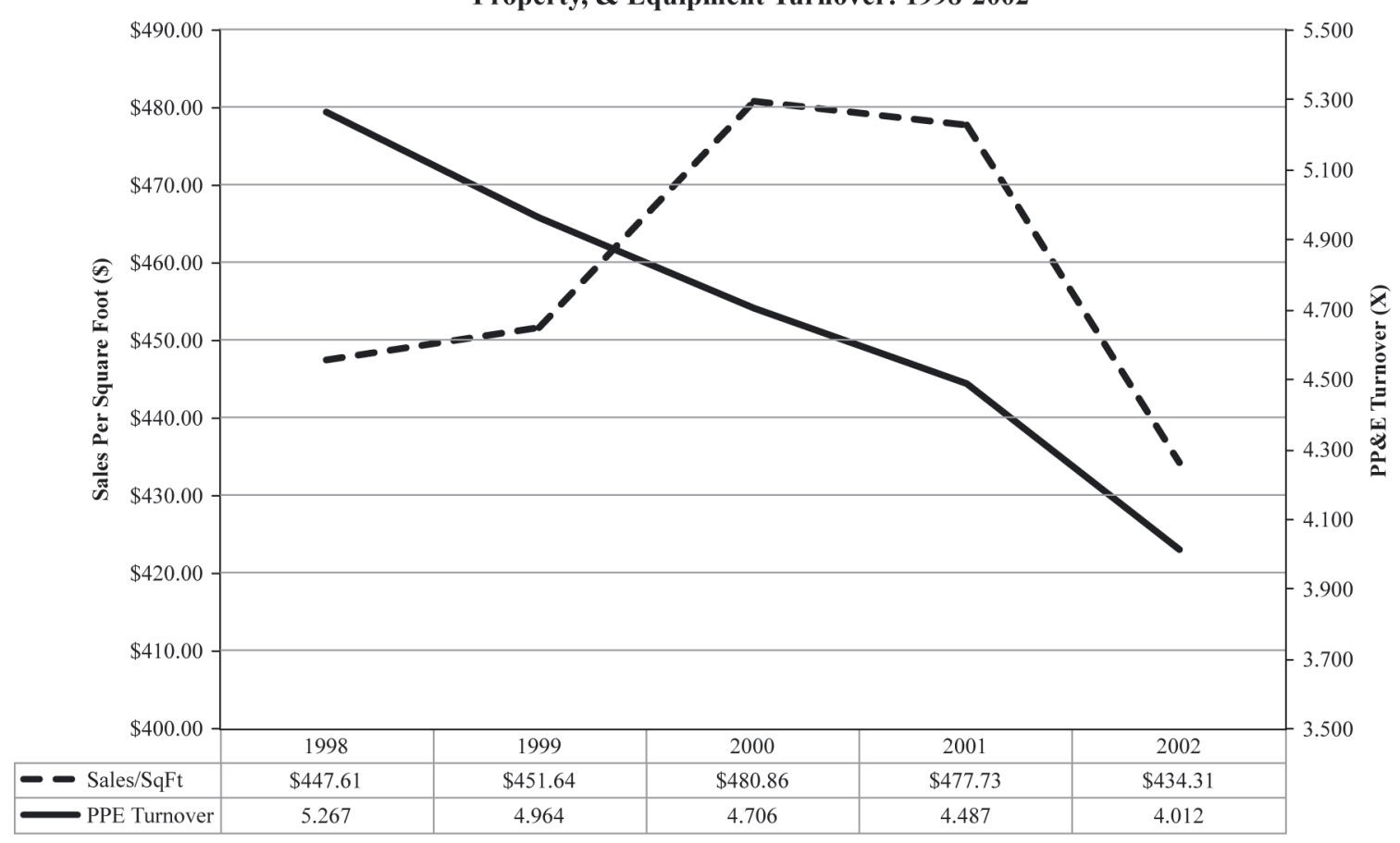

Source: S\&P Capital IQ-Compustat North American database 
Figure 6 Safeway Company

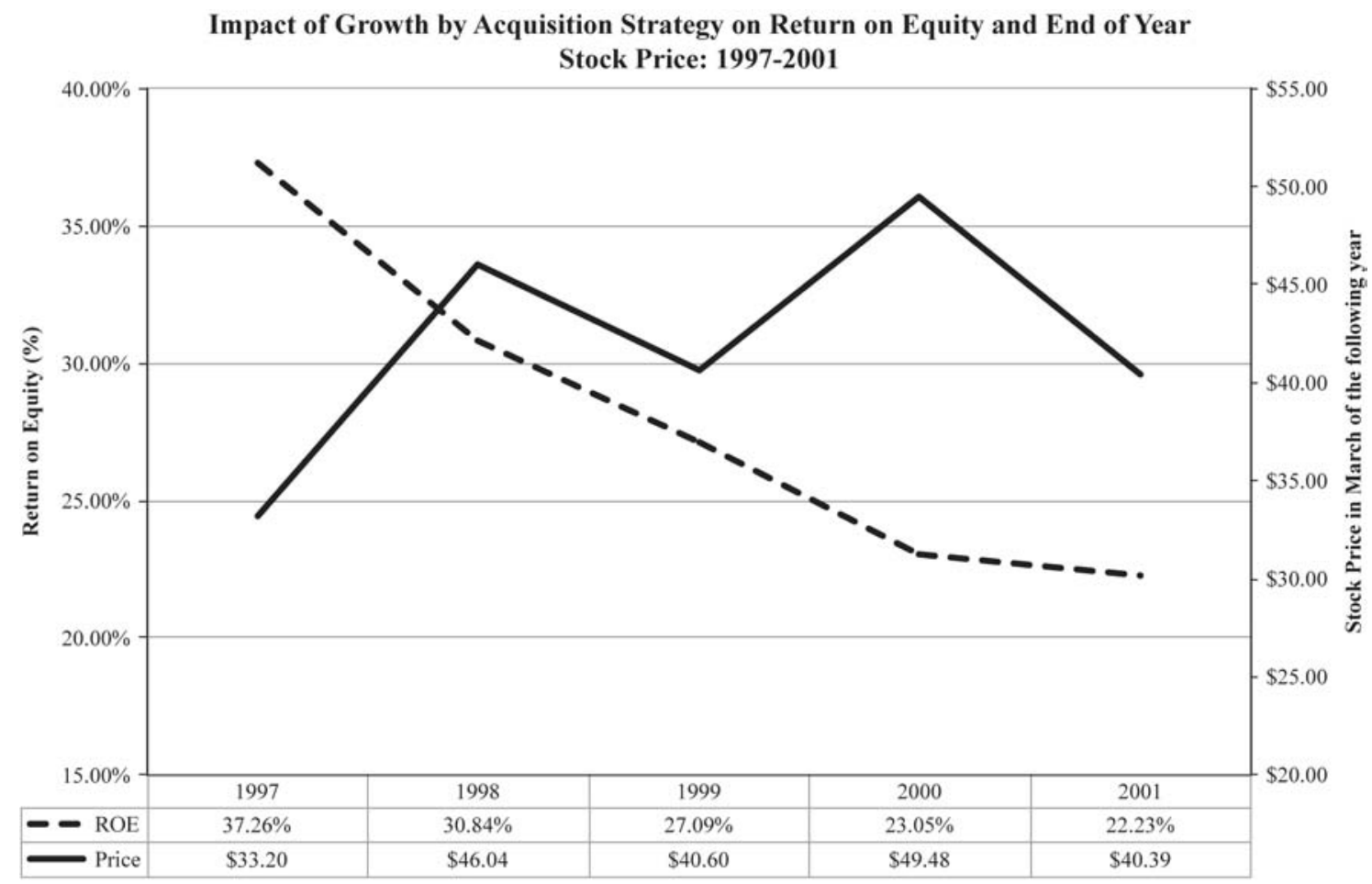

Sources: ROE: S\&P Capital IQ-Compustat North American database; Price: Finance.Yahoo.com

Figure 7 Safeway Company

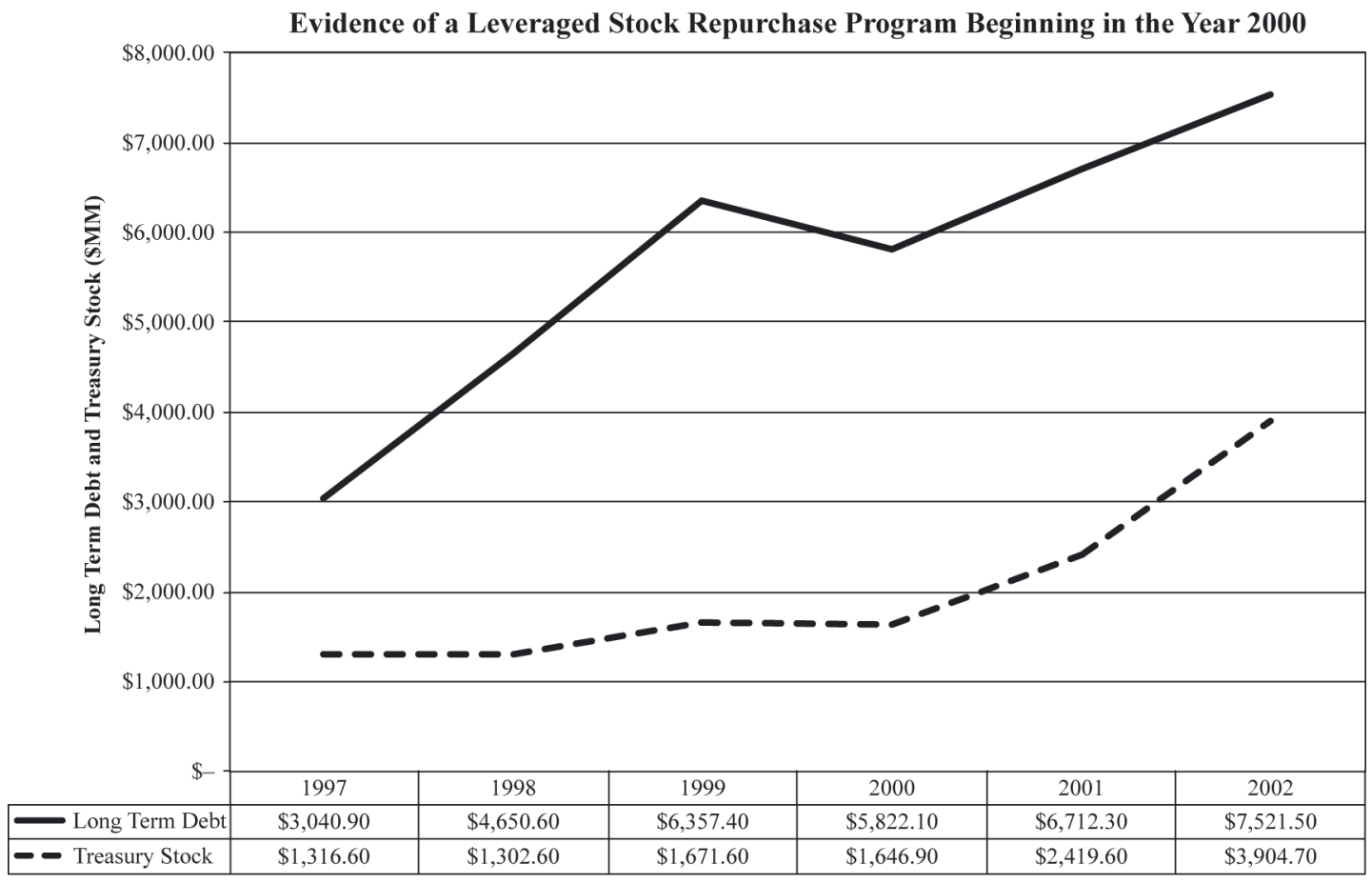

Source: S\&P Capital IQ-Compustat North American database 
Figure 8 Safeway Company

Monthly Stock Price (Adjusted for Splits): Feb. 2002-Sept. 2005

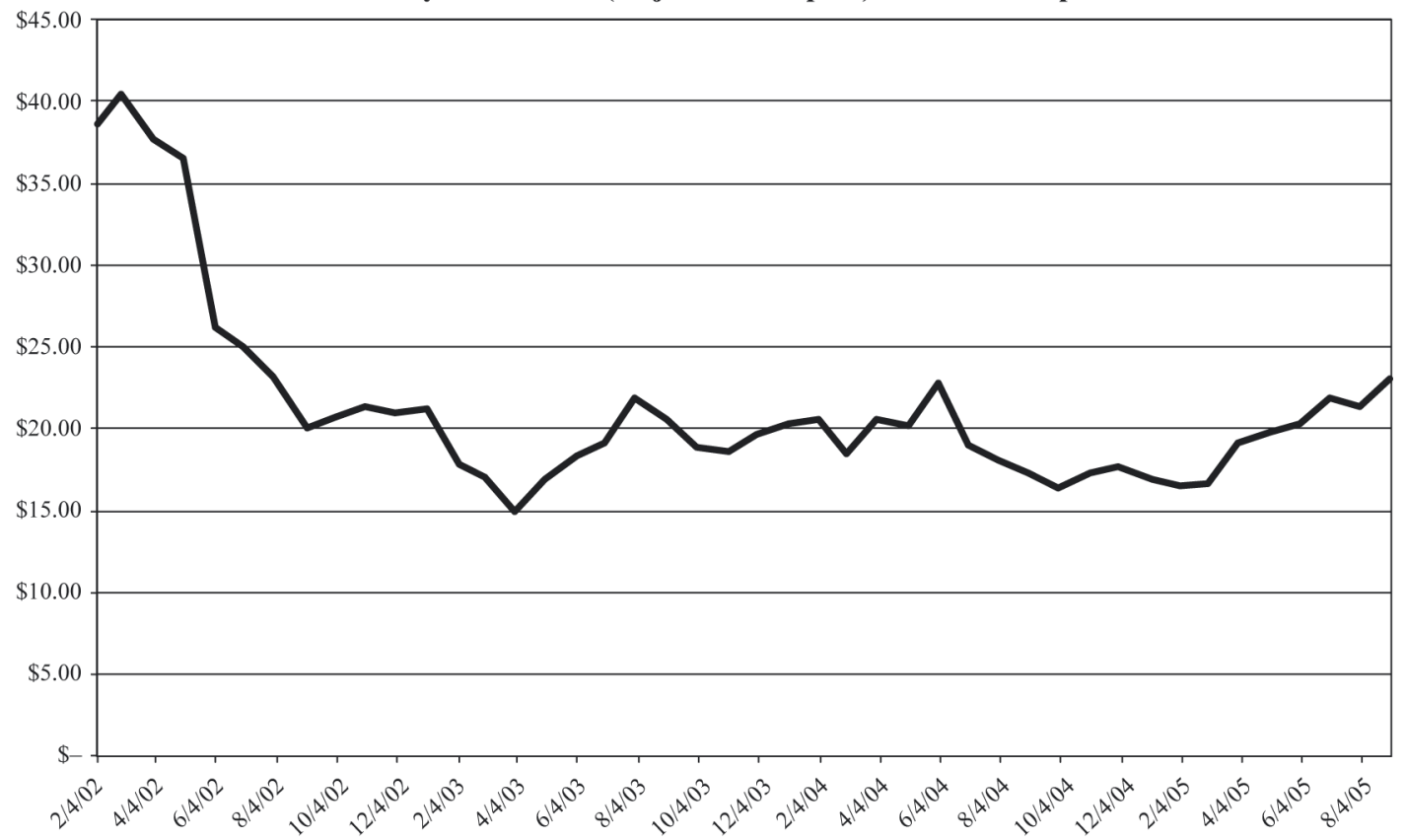

Sources: Finance.Yahoo.com; Stock prices adjusted for dividends

In addition, Safeway also began to sell off some of the store assets it had acquired over the same time period, namely, the Dominick's chain. Over $\$ 2.20$ billion of intangible asset value was either written down or sold off Safeway's balance sheet in 2002 alone. From April 2003 through September 2005, the stock would continue to trade in the range of $\$ 14$ to $\$ 23$ per share.

The overall impact of Safeway's growth by acquisition strategy was the deterioration of its operating return on assets. Operating return on assets is measured by dividing the operating profit by the average asset level for a given year. It is a good way to measure the impact on the ROE generated by the physical operation of a business. Using net income, as in the traditional measure of ROA, confounds the understanding of the impact of operating strategy because it includes a measure of interest expense, which results from the financial policy decisions made by a firm. Operating ROA, on the other hand, is not affected by interest expense or other financial decisions of the firm.

As can be seen in Figure 9, the operating return on assets steadily declined from the beginning of the growth by acquisition strategy until it turned up in 2006. By then, Safeway had been engaged in a rebranding process that had begun two years earlier.

The analysis demonstrates that Safeway's brand acquisition strategy failed and highlights some important factors that brand managers must consider. Most important, brand acquisition does not explicitly focus on brand equity. It tends to consider market share first, without emphasizing the customer-brand bond. Combining to achieve market share may or may not include efforts to segment and differentiate carefully and increase customer satisfaction. If the brand acquisition takes a "Lego block" approach, each piece may be quite different and lack consistency and synergy.
Other factors to be managed carefully in a brand acquisition strategy are:

- Determining the acquisition price.

- Establishing economies of scale.

- Maintaining consistency of the brand image.

- Integration: whether the branding and culture of the acquired company or assets fits into the acquirer's existing brand strategies and culture.

- Whether the company understands the specific value of the acquired brand and how to manage it (e.g., does the brand equity depend on understanding a specific regional market in which the company hasn't operated).

\section{Safeway's "lifestyle" rebranding: 2004-2008}

Beginning in 2004, Safeway commenced an organic rebranding strategy referred to as "Lifestyle." The rebranding called for remodeling of stores to include larger produce and specialty departments, wood-grain flooring, improved lighting and other features designed to attract a more upscale customer base. Product mix was altered to include a variety of Safeway brands designed to have higherend customer appeal, such as the Safeway "Select" and "OOrganics" products. The latter addition was part of a strategy to compete with stores such as the Whole Foods Market and other higher-end natural and specialty markets by offering broader lines of organic, natural, and international food products. Additionally, greater emphasis was put on takeaway food for lunches and dinners. Bulk package goods such as napkins and paper towels were de-emphasized, and less space was devoted to products such as these. Finally, crossmarketing opportunities were created by the addition of fuel stations to many of the stores. 
Figure 9 Safeway Company

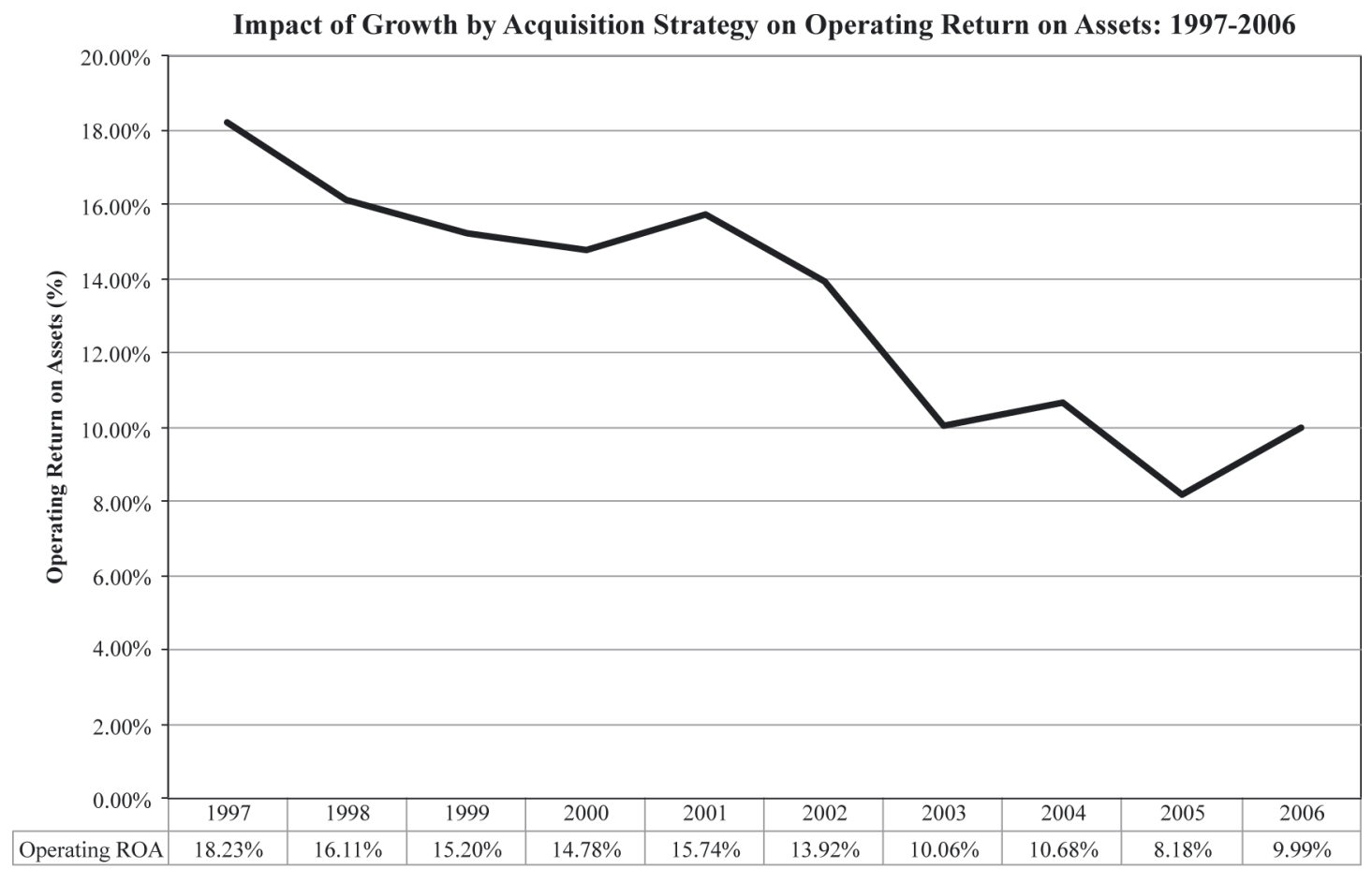

Source: S\&P Capital IQ-Compustat North American database

The rebranding effort led to significant changes to the physical assets the firm. As can be seen in Table I, the number of stores actually decreased from 1,802 at the end of 2004 to 1,739 in 2008 , reversing the trend created by the acquisition strategy of the prior seven years. Total retail square footage was reduced from 82.1 down to 80.4 million. Over the same period of time, 1,235 of the stores were remodeled, resulting in cumulative cash capital expenditures of $\$ 7.634$ billion over the five years.

The initial impact of the strategy was highly favorable. As can be seen in Figure 10, sales per square foot increased by $\$ 112.57$, to a level of $\$ 548.90$ by 2008 . In addition, inventory turnover increased from 9.04 to 11.30 . The economic events of 2008-2009, however, exposed the upscale rebranding's strategy to its primary vulnerability: recession.

\section{Safeway's lifestyle rebranding and the recession: 2002-2011}

As shown above, the initial impact of the Lifestyle rebranding on Safeway's performance was favorable. The growth in sales per square foot was led by overall sales growing from just over $\$ 32$ billion in 2002 to over $\$ 44$ billion in 2008 , as can be seen in Figure 11. This was apparently aided by a decrease in the gross profit margin, which fell by 270 basis points over the same time period.

Safeway was hit hard, however, by the recession and financial market crisis of 2008-2009. As can also be seen in Figure 11, sales actually fell to $\$ 40.8$ billion in 2009 , and have yet to recover to their 2008 levels. Safeway's gross profit margin has also narrowed by an additional 133 basis points, down to a level of 29.66 percent, putting additional pressure on operating and net profit margins.

As the Lifestyle rebranding strategy took hold, improvements were noticeable in some of the asset turnover ratios. As can be seen in Figure 12, in spite of a minor decrease in Net PP\&E turnover resulting from the high rate of capital expenditures on the store remodeling activities, both net fixed asset and total asset turnover ratios increased slightly from 2004 to 2008. This is not surprising given the improvements in inventory turnover and sales per square foot observed for the same time period.

Table I Safeway Company. Impact of lifestyle rebranding on number of stores, remodeling activity, retail square footage, annual capital expenditures and sales per square foot: $2004-2008$

\begin{tabular}{lcccccc}
\hline FYE & 2004 & 2005 & 2006 & 2007 & 2008 & Total/change \\
\hline Stores at year end & 1,802 & 1,775 & 1,761 & 1,743 & 1,739 & 253 \\
Store remodels & 115 & 315 & 284 & 268 & 1,235 \\
Retail square footage (millions) & 82.1 & 81.0 & 80.8 & 80.3 & 80.4 & 1.7 \\
Cash capital expenditures (\$) & 1.212 .50 & $1,383.50$ & $1,674.20$ & $1,768.70$ & $1,595.70$ & $7,634.60$
\end{tabular}

Source: Safeway Annual 10-K report (2008) 
Figure 10 Safeway Company

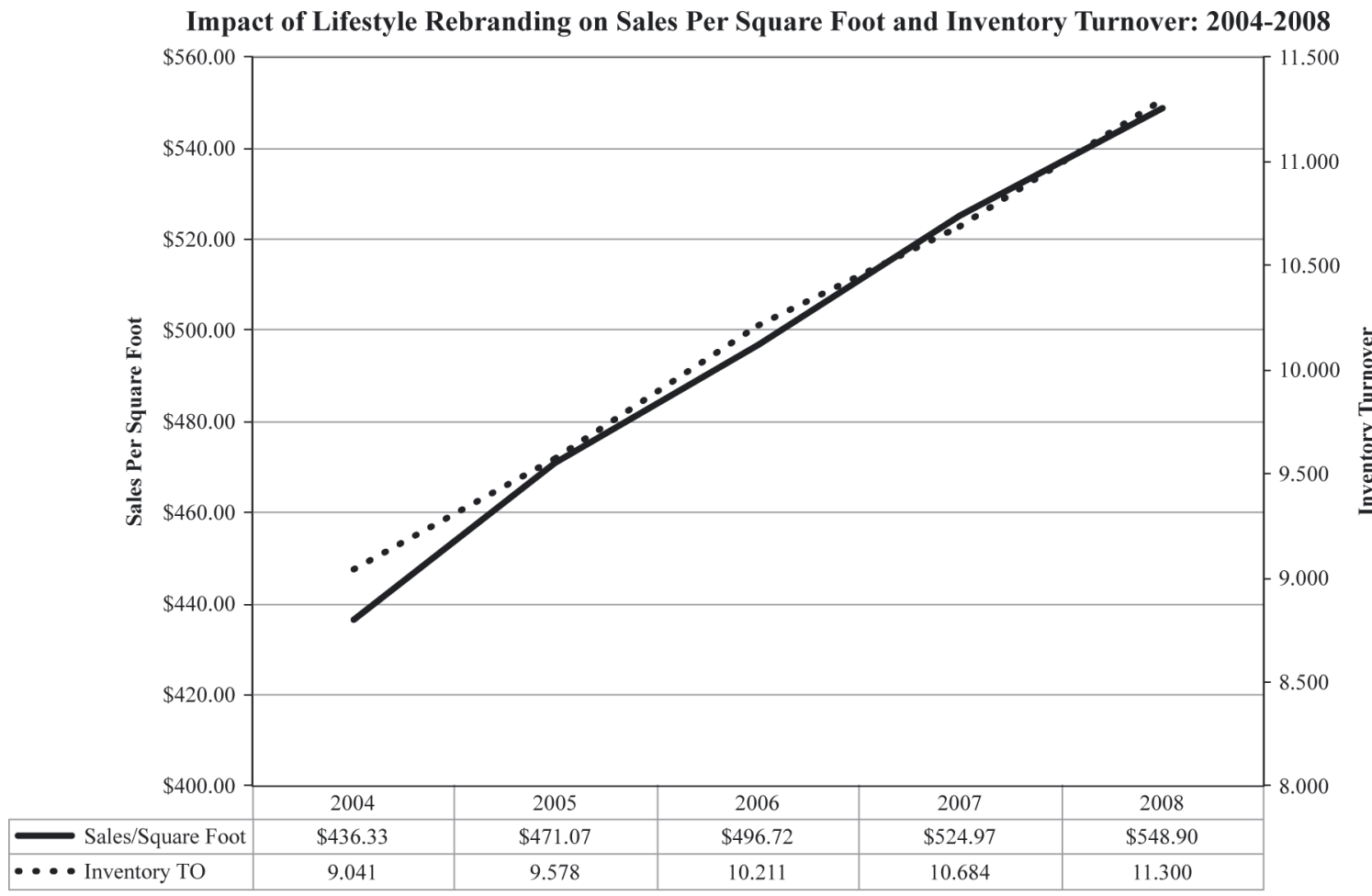

Source: S\&P Capital IQ-Compustat North American database and Safeway Annual 10-K report, 2008

Figure 11 Safeway Company

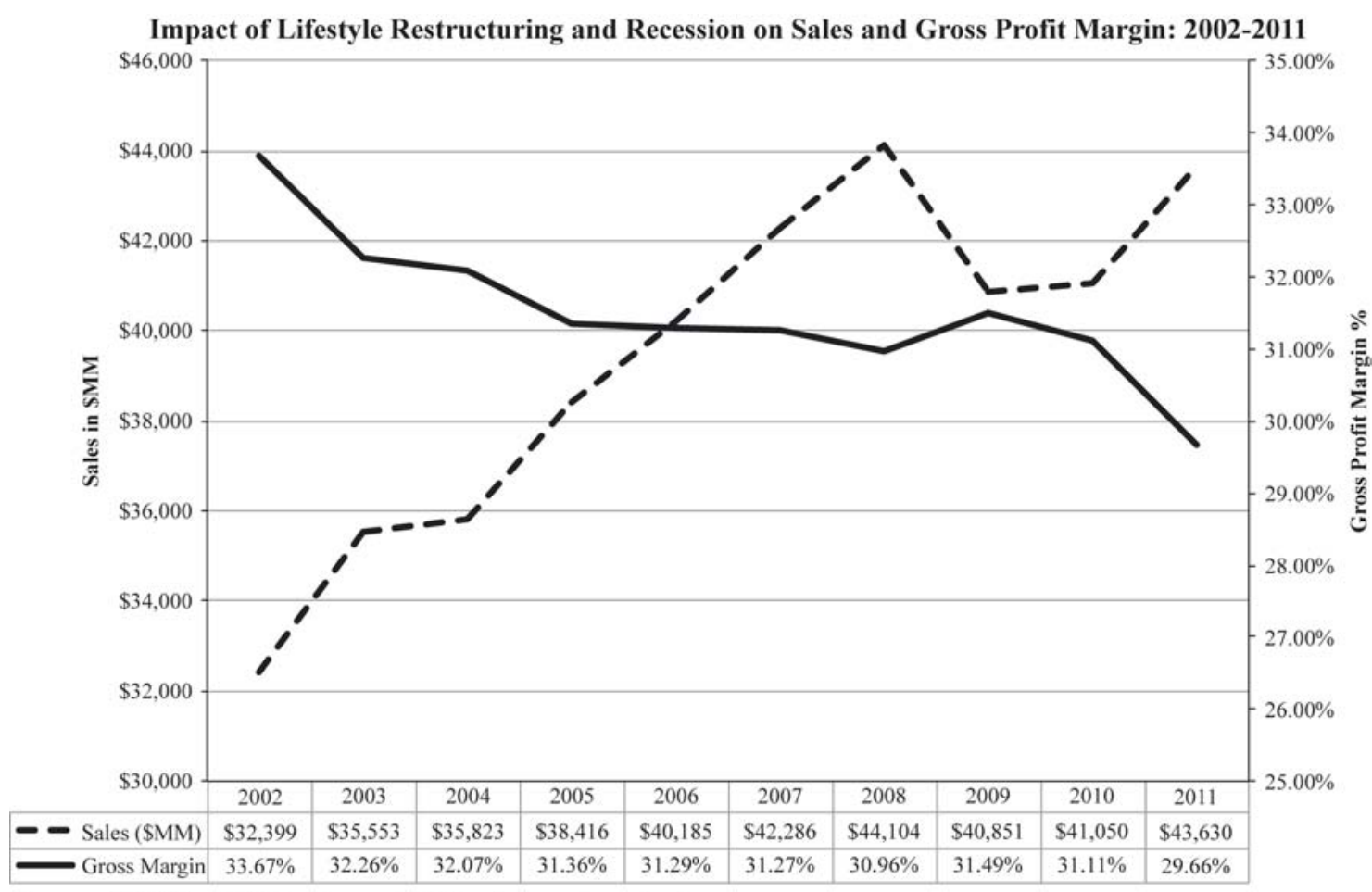

Source: S\&P Capital IQ-Compustat North American database 
Figure 12 Safeway Company

Impact of Lifestyle Rebranding, Recession, and Goodwill Impairment on Asset Turnover Ratios: 2004-2011

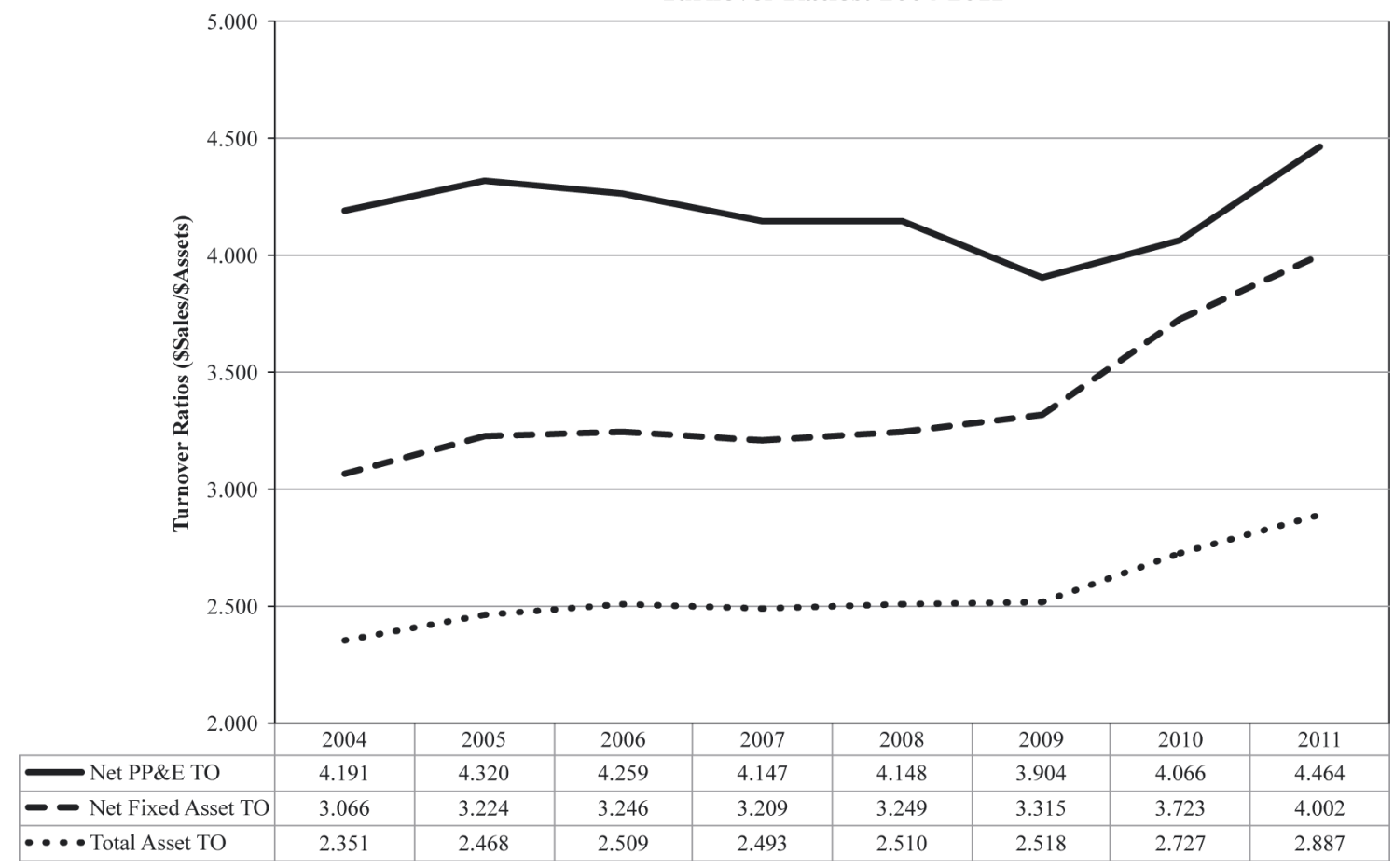

As did many other companies at the time, Safeway took advantage of the stock market crash of the fall of 2008 to write-down most of the goodwill and other intangible value added to its balance sheet as a result of the external brand acquisition strategy of 1997-2001. This took the form of a $\$ 1.97$ billion charge against earnings for 2009 , and resulted in the intangible asset value to fall to just about $\$ 400$ million by the end of that year, a far cry from the over $\$ 5.0$ billion amount at the apex of the acquisition strategy.

The main benefit of the impairment was to improve the asset turnover ratios for the following years. As can be seen in Figure 12, the goodwill impairment reduced the value of the net fixed and total assets, reducing the denominators of the associated turnover ratios, and increasing their values. Likewise, the capital spending program surrounding the Lifestyle rebranding was put on hold, leading to a stabilization of the value of the Net PP\&E, and a rising Net PP\&E turnover for 2010-2011.

The most telling impact of the recession and subsequent sluggish economy on the success of Safeway's Lifestyle rebranding strategy is evident in the operating return on assets. As can be seen in Figure 13, operating ROA had continued its decline until 2006, when the momentum gained by the rebranding enabled it to turn around, climbing back to just over 10.50 percent in 2008. The ratio has steadily declined ever since, falling to a low of 7.55 percent in 2011. This again demonstrates the vulnerability of an upscale brand strategy in a competitive retailing environment.

\section{Safeway's response: re-emphasis on financial strategy}

The initial successes of the Lifestyle rebranding strategy were also reflected by improvements in Safeway's stock price. As can be seen in Figure 14, the stock value had risen to just over $\$ 33$ per share by March of 2007. By that time, however, signs of a recession were beginning to develop, and the stock value started to decline. While making temporary gains in November 2007 and March 2008, the stock fell to a low of $\$ 17.18$ by February 2009, losing all that it had gained during the period of the Lifestyle rebranding. Since then it has traded in the range of $\$ 16-24$ per share.

In response to the turns in the economy and stock market, Safeway has refocused its efforts on managing its financial strategy, namely, its use of leverage and equity repurchase programs. As can be seen in Figure 15, Safeway steadily reduced its long-term debt from 2003-2010. This put downward pressure on the leverage multiplier component of the ROE, which can be seen in the Figure 15 to fall from 4.283 down to 2.605 between 2003 and 2008. As early as 2006, however, Safeway resumed its program of treasury stock repurchases. As can be further seen in Figure 15, this program accelerated after the market crash in 2008. Between then and the end of 2011, Safeway repurchased over $\$ 4.0$ billion in treasury stock. Some of this repurchase activity has been supported by additional debt financing, as can be seen by the increase in long-term debt for 2011 . The overall impact of the repurchase plan has been to increase the leverage 
Figure 13 Safeway Company

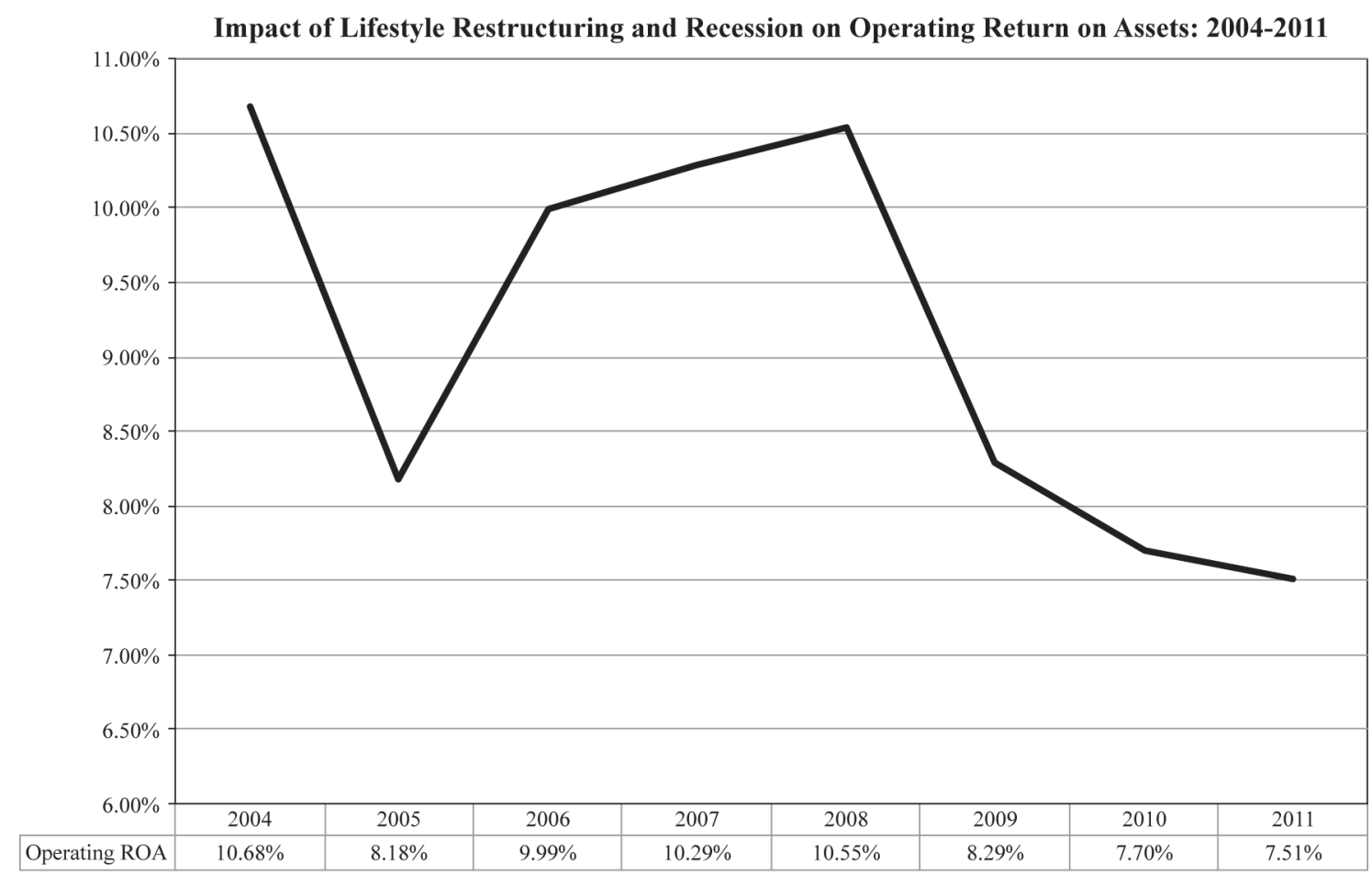

Source: S\&P Capital IQ-Compustat North American database

Figure 14 Safeway Company

Monthly Stock Price: Jan. 2003-Dec. 2011

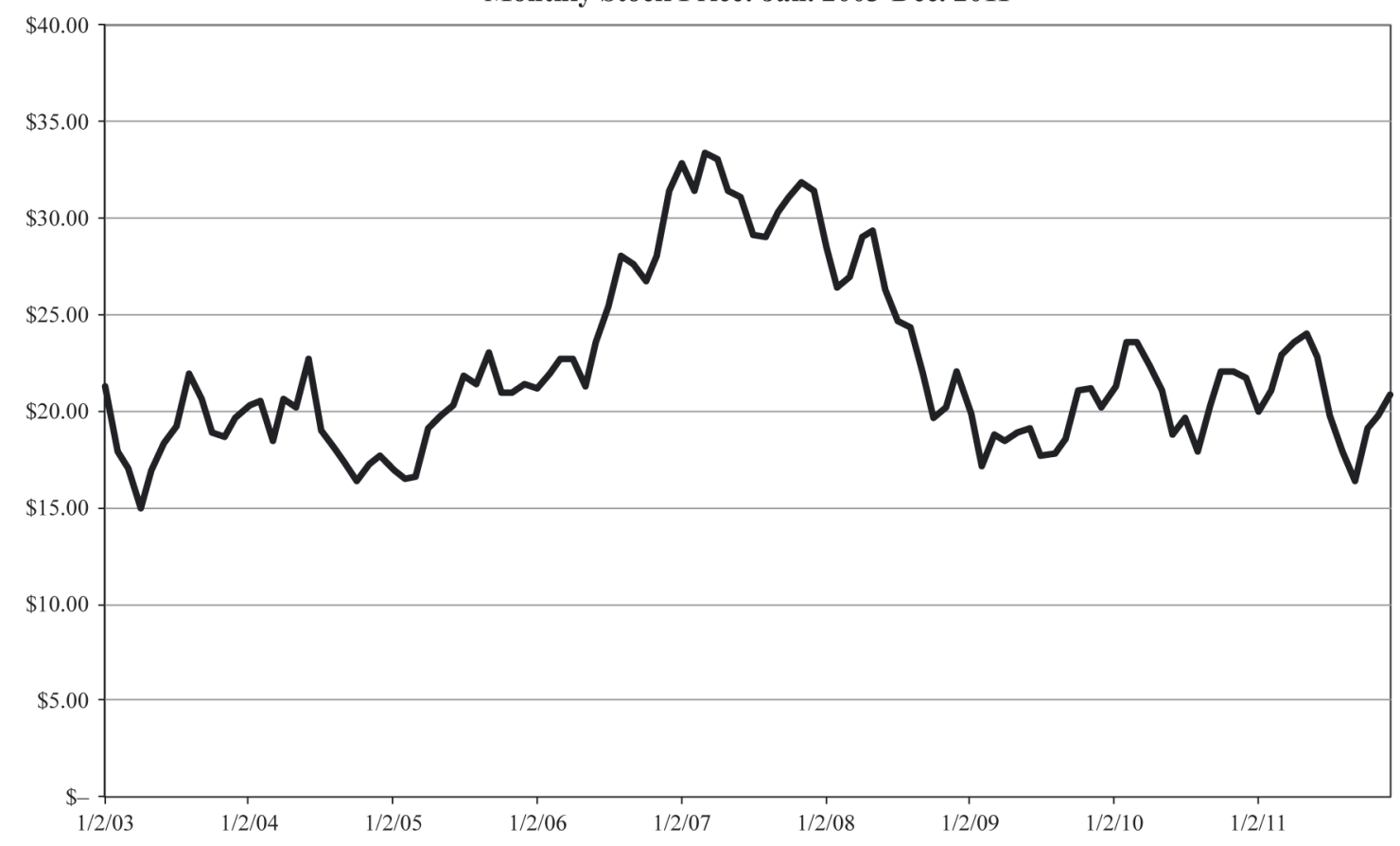

Sources: Finance.Yahoo.com; Stock prices adjusted for dividends 
Figure 15 Safeway Company

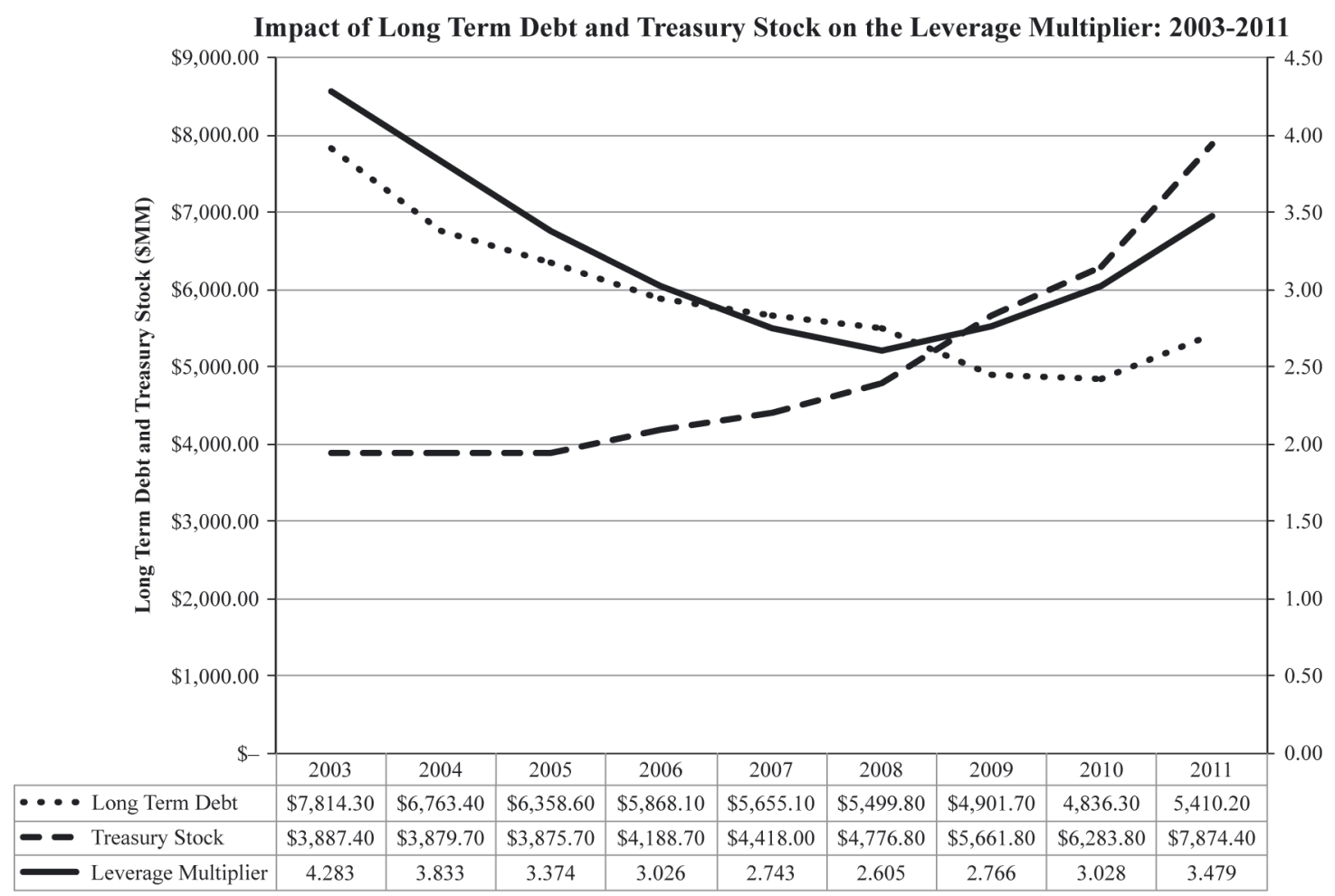

Source: S\&P Capital IQ-Compustat North American database

Figure 16 Safeway Company

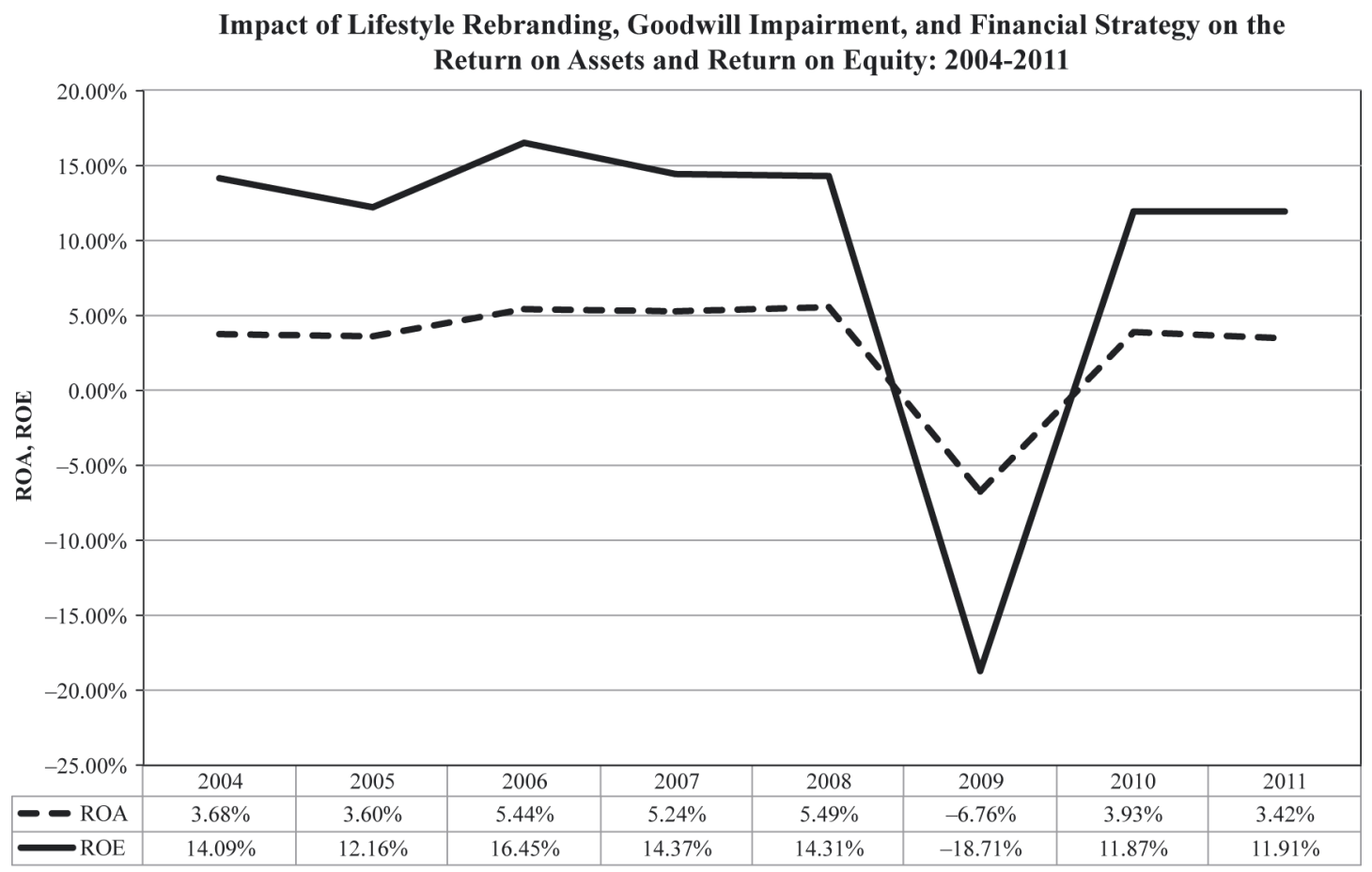

Source: S\&P Capital IQ-Compustat North American database 
multiplier component of the ROE, as can be clearly seen in Figure 15.

Safeway's return on assets (ROA) and return on equity (ROE) both demonstrate the impacts of the goodwill impairment charges taken in 2009 and, in the case of the ROE, the increased use of leverage by the firm. As can be seen in Figure 16, both the ROA and ROE spiked downward in 2009 as the impairment charge led to negative net income for that year. Reducing the asset value by the impairment charge, however, reduced the denominator of the total asset turnover components of both the ROA and ROE, enabling each to increase in 2010. While the ROA has since fallen slightly, the ROE remains stable and at a level much higher than the ROA due to the increased use of leverage by the firm (i.e. the stock repurchase program reduces outstanding equity values relative to the firm's debt level). As a result, further declines in the stock price have, at least for now, abated.

One key question remains: Is Safeway's financially driven strategy sustainable in the longer run? Safeway has used significant amounts of cash to repurchase shares and maintain the market value of its stock at a time when sales and profit growth are sluggish. Recent experience has taught them that there may be few, if any, substantial growth opportunities remaining in the retail grocery industry, at least for now. Even WalMart has curtailed its growth and development of markets in the domestic USA.

\section{Lessons learned}

As long as Safeway can continue to generate a cash flow and return it to its investors in the form of regular and/or liquidating (share repurchase) dividends, the stock value may hold and the overall business model may be sustainable. If overall economic growth resumes, Safeway may once again experience growth in sales and profitability. Even so, a highleverage strategy is more risky in a competitive retailing environment where many of the goods take the form of commodities. It will require careful and judicious management in the near future.

Financial analysis provides some evidence that Safeway's brand development strategy was inherently more successful than its growth by acquisition efforts. The results are in line with marketers' expectations that concentrating on the customer's wants and expectations in terms of price, quality and convenience is the pathway to success. Safeway's financial based strategy of repurchasing stock to maintain market value complicates the assessment. However, the key values generally support the notion that concentrating on the brand and the customer in a consistent manner, namely brand development, is the more effective strategy.

\section{References}

Bahadir, S.C., Bharadwaj, S. and Srivastava, R. (2008), "Financial value of brands in mergers and acquisitions: is value in the eye of the beholder?", Fournal of Marketing, Vol. 72, November, pp. 49-64.

Mizik, N. and Jacobson, R. (2008), "The financial value impact of perceptual brand attributes", Fournal of Marketing Research, Vol. XLV, February, pp. 15-32.

M'zungu, S., Merrilees, B. and Miller, D. (2010), "Brand management to protect brand equity: a conceptual model", Brand Management, Vol. 17 No. 8, pp. 605-17.

Simon, C. and Sullivan, M. (1993), "The measurement and determinants of brand equity: a financial approach", Marketing Science, Vol. 12 No. 1, Winter, pp. 28-52.

Ward, K. and Ryals, L. (2001), "Latest thinking on attaching a financial value to marketing strategy: through brands to valuing relationships", fournal of Targeting, Measurement and Analysis for Marketing, Vol. 9 No. 4, pp. 327-40.

\section{About the authors}

Steven Isberg is an Associate Professor of Finance in the Finance and Economics Department at the University of Baltimore.

Dennis Pitta is Professor of Marketing and chair of the Marketing \& Entrepreneurship Department at the University of Baltimore. Dennis Pitta is the corresponding author and can be contacted at: DPitta@ubalt.edu 